\title{
Emergency Communications and Alerting Systems for Fire Brigades in Baden-Württemberg - Much Room for Improvement?
}

\author{
Eva Gräßle ${ }^{1}$ and Robert Müller-Török ${ }^{2}$
}

\begin{abstract}
Most of the fire brigades in Baden-Württemberg are volunteer forces, hence creating the need for readily available and reliable alerting and communication systems for these forces as well. Digital Pagers are the standard means of alerting but, due to their limited reliability, alternative and complementary methods like Apps, SMS, etc. are also used by these volunteer forces. Regarding communication at the scene, the transition from open analogue to encrypted digital radio systems has been on its way for nearly 20 years. As of today, new technology is available for police forces whilst fire brigades still have to use analogue systems. This contribution analyses the situation, past and present, planning and attempts at improvement.
\end{abstract}

\section{Introduction}

In recent years a significant increase in large scale emergencies, caused by terrorism and crime, was observed in "The West", namely in the USA and UK, France, Belgium and also in Germany. The violence during the G20 summit in Hamburg 2017 [6, 7, 8] and the deadly attack by an Islamic terrorist, with a truck, on the Christmas Market on Breitscheidplatz in Berlin [9, 10], were not simply police issues but they also called for the fire brigades' involvement. Terrorist attacks in the past included trucks (Nice and Berlin), cars (London) and, never to be forgotten, by airplanes in the 9/11 attack against the Pentagon and the Twin Towers in New York. Police assisted in the latter, but it was mainly an operation by the Fire Department of New York (FDNY). So the issue of alerting and communicating systems for fire brigades becomes more vital, especially when we consider combined attacks against airports, refineries or chemical plants, all of which can occur in a quite remote and peaceful land like Baden-Württemberg ${ }^{3}$.

The municipalities - in Baden-Württemberg, 1.101 entities plus 35 counties or "Landkreise", have the legal obligation to organize fire brigades, each as "a capable fire brigade according to the local requirements" (§ 3 (1) FwG BW, our translation), which leaves a lot of room for interpretation. The municipalities must organize it on their own, i.e. they are not bound by any orders from a central authority such as the Federal State Ministry of the Interior (see $\S 2$ (2) FwG BW). According to the interpretation of the Federal State Association of Fire Brigades, the term "capable" means

\footnotetext{
1 Civil Servant, City of Schwieberdingen, Schloßhof 1, D-71701 Schwieberdingen. The views expressed in this paper are the private opinion of the author.

2 Professor, University of Public Administration and Finance Ludwigsburg, Reuteallee 36, 71634 Ludwigsburg, Germany. Email: mueller-toeroek@hs-ludwigsburg.de

${ }^{3}$ The Kelley Barracks, HQ of the United States Africa Command AFRICOM are only 5 kilometers away from Stuttgart International Airport; the world's biggest chemical plant, BASF Ludwigshafen is situated in the twin cities of Ludwigshafen-Mannheim, the latter belonging to Baden-Württemberg and the largest refinery of Germany, MiRo is situated in the Baden-Württemberg town of Karlsruhe [2].
} 
- Response Time, i.e. the time in which a dispatched fire engine arrives on the scene

- Firefighters, i.e. sufficient staff available on the scene

- Equipment available on the scene should be appropriate [3].

This leaves much room for discussions between councilors, civil servants, mayors and of course firefighters, about the necessary equipment, the topic on which we focus in this paper. In the following sections, we describe the state of alerting and communicating systems and finally ask if they appear to be sufficient for likely events such as major terrorist attacks or other large scale incidents.

In Germany the Ambulance Service is mostly provided by the Fire Brigades ${ }^{4}$, only a minor share of the service being provided by the German and Bavarian Red Cross and private entities. The emergency number 112 is both for fire brigade related and medical emergencies and is mostly operated by the local fire brigade command.

\section{Some core figures on the fire brigades of Baden-Württemberg}

Fire brigades in Baden-Württemberg belong to the so called "Authorities and Organizations tasked with Security" and are organized in voluntary fire brigades and in professional brigades consisting of regularly employed firefighters. A professional fire brigade is mandatory for municipalities with more than 100,000 inhabitants - a criterion not met by many, hence there being only some 2,100 professional firefighters serving in the Federal State [4]. In addition, some companies are required to run their own fire brigades 5 , e.g. the above mentioned BASF for their chemical plant.

In the whole Federal State a total of some 116,676 firefighters served, as per 2016 [5], which means that roughly two percent of the firefighters are professionals, the vast majority being volunteers.

\section{Alerting Systems}

To provide alerting systems is the task of the counties and the Federal State does not provide such systems (see $\S 4$ (3) FwG BW). The current alerting system is the Digital Pager. Quite handy, approximately the size of a cigarette box, it is equipped with a small display and a small keyboard. The system in Baden-Württemberg is based on the $2 \mathrm{~m}$ frequency band which is reserved for alarm warnings only, so that the $4 \mathrm{~m}$ band can be used for communications on the scene. In recent years additional systems were introduced but they only supplemented the Digital Pager which is the sole official means of alerting/warning/alarming.

The costs for such additional systems cannot be borne by the counties, their legal obligation to provide an alerting system being fulfilled by the Digital Pagers. Such systems are mainly SMS or App-based. These costs can be borne by the respective municipality but some of them refuse, citing the Digital Pagers.

\footnotetext{
${ }^{4}$ Namely in larger cities like Munich, Hamburg, Berlin, Essen etc. In rural areas the Red Cross and other organizations operate a larger share of the ambulance services.

${ }^{5}$ See $\S 19(1)$ FwG (BW).
} 
Additional systems have a positive effect if the main alerting system is not available. Some counties and municipalities have legal doubts, especially when the alarm concerns not a fire brigade issue but an ambulance issue. In the latter case sensitive personal data is transferred via a non-secure network, such as the internet or the mobile phone network, such that the dispatchers in the county of Ludwigsburg refrained from using these additional alerting systems (see [1], p. 16). Note that the mobile phone networks in Germany use AES in versions of a grade lower than A5/3. The biggest German mobile phone network provider, Deutsche Telekom AG, announced the introduction of A5/3 in late 2013 [11]. Even in 2018 we cannot be sure that all providers will use an advanced encryption standard, which cannot be hacked into in real time, as was the case with the outdated A5/1 standard [18].

\section{Communication Systems}

Open analogue radio is unfortunately still the standard when it comes to communications on the scene. The conference of the Ministers of the Interior of Germany announced the introduction of encrypted digital radio systems in 1996, but the replacement is far away from being implemented (see [1], p. 25). A major issue with the analogue radio is that any communication can be intercepted easily - given a scenario of a planned terrorist attack, like that in Mumbai on November $26^{\text {th }}, 2008$, the terrorists will have the necessary equipment to intercept the communications of the emergency services [12].

After several political acts since 1996 finally, in 2006, a Federal Agency was founded with the task of introducing a standardized, encrypted digital radio system for all the relevant organizations in Germany - a task not yet completed. As of 2017 the police forces used digital radio, but not the "non-armed" organizations like Fire Brigades, Red Cross and the THW'.

This leads to another major shortcoming of the current regime: e.g. if Federal State Police, local Fire Brigade, Red Cross and Commandos from the Federal Police work together on one scene, how shall they communicate? They have no common system and there is no interoperability between digital and analogue radio. The lucky Fire Brigades, whose counties and municipalities financed their transition to encrypted digital radio, must also bring their old analogue radios with them in order to be able to communicate with the less fortunate forces on the scene.

Other countries, despite being at the same industrial and economic level as Germany, have similar issues. Japan has transformed its respective fire prevention organizations within the last years; according to industry sources [see 19, p. 53]. The advantages of digitized wireless communications are quite obvious [see 19, pp. 55].

\section{Availability of the Alarm and Communication Systems}

Scenarios like Mumbai 2008, where the siege of the Taj Mahal Hotel lasted for three days, or Paris Bataclan, can easily last for many hours so the question arises on the availability of the communication systems of the emergency forces. Imagine that telephones and the power grid are down, at least for a while and look what happens:

\footnotetext{
${ }^{6}$ Technisches Hilfswerk, a German Federal Agency in charge of Disaster Relief Operations nationwide and also worldwide.
} 


\subsection{Availability of the Digital Pagers}

The dispatcher system becomes redundant and decentralized; such availability can be taken for granted (see [1], p. 41).

\subsection{Availability of additional alerting systems, SMS or app. based}

Both, SMS and App are heavily dependent upon the availability of the mobile phone network and the internet, e.g. as shown on http://allestörungen.de/, a website collating all errors and instances of non-availability of German Telecommunication Providers. Local non-availability is quite normal, both of mobile phone network and internet services.

\subsection{Availability of the open analogue radio}

Given power supply, which is also provided from fire engines, the availability of this is very high.

\subsection{Availability of the encrypted digital radio}

A formal inquiry to the Federal Government by a Member of Parliament in 2016 showed a very disappointing result: A failure of the national power grid can be compensated for, by a decentralized power supply for only two hours [13]. This means that after just two hours, the encrypted digital radio used by police forces is no longer available. Further evidence shows that this is not the only shortcoming of the digital radio systems operated:

- On July $22^{\text {nd }}, 2016$ a juvenile went on a killing spree in Munich. Digital Radio of the Bavarian Police forces was unavailable for minutes, forcing the police to resort to the use of private mobile phones [14]

- $\quad$ On New Year's Eve in Cologne the Digital Radio of the Cologne Police was unavailable [15]

- $\quad$ During the recent terrorist attacks in Brussels, Belgian Police had to resort to WhatsApp (sic!) because their digital radio did not work [16]

Without discussing this alarming issue further, it is worth mentioning that the Senate of the Federal State of Berlin, the capital of Germany, voted in 2017 to buy some 16,000 regular mobile phones for the Berlin Police - simply because the Digital Radio available is not reliable [17].

\section{Resume}

Modern Alerting and Communication Systems can definitely bring added value to both the fire brigades and the society served. Due to the massive trend towards digitalization, current alerting systems must be changed, bearing in mind that new technologies are not per se 100 percent reliable and can be interrupted with little effort. Digital pagers will likely remain the most reliable alerting method. The big issue seems to be the analogue radio systems which still operate, the transition to encrypted digital radio systems is still on its way, even after a decade and its completion cannot be predicted with any certainty.

A major security issue is the limited availability of emergency power supply for the digital radio systems - two hours is definitely not sufficient when compared to the current threat scenarios, which include daylong stand-offs and operations lasting far more than two hours. 


\section{References}

[1] Moderne Alarmierungs- und Kommunikationssysteme der BOS - Eine kritische Betrachtung am Beispiel der Feuerwehr. Bachelor Thesis, University of Public Administration and Finance Ludwigsburg by Eva Gräßle, 2017.

[2] "Der Karlsruher Ölriese - Deutschlands größte Raffinerie", by Robin Szuttor, in Stuttgarter Zeitung, 4.12.2012.

[3] Landesfeuerwehrverband Baden-Württemberg e.V.: Hinweise zur Leistungsfähigkeit der Feuerwehr, Seite 3; URL: http://www.fwvbw.de/fileadmin/Downloads/allgemein/Hinweise zur_Leistungsf\%C3\%A4higkeit_einer_Feuerwehr.pdf (as per 25.08.2017)

[4] Landesfeuerwehrverband Baden-Württemberg e.V.: Feuerwehren, Berufsfeuerwehr; URL: http://www.fwvbw.de/berufsfeuerwehren,92.html (as per 28.07.2017).

[5] Landesfeuerwehrverband Baden-Württemberg e.V.: Zusammenfassung der Jahresstatistik 2016; URL: http://www.fwvbw.de/fileadmin/Downloads/Aktuelles/Auswertung_Statistik_ 2016.pdf (as per 11.08.2017).

[6] "Hamburg braces for G20 violence as tensions rise over police tactics", in: The Guardian, 05.07.2017; URL: https:/www.theguardian.com/world/2017/jul/05/hamburg-braced-for-huge -violent-protests-in-run-up-to-g20-summit_(as per 16.02.2018).

[7] “Arrests and injuries as Hamburg gripped by mass anti-G20 protests “, in: The Guardian, 07.07.2017; URL: https:/www.theguardian.com/world/2017/jul/07/g20-protests-hamburgaltona-messehalle (as per 16.02.2018).

[8] "Violence on Hamburg streets as G20 protests descend into chaos", Video, in: The Daily Mail (Mail Online); URL: http://www.dailymail.co.uk/video/news/video-1496997/ViolenceHamburg-streets-G20-protests-descend-chaos.html_(as per 16.02.2018).

[9] "Police investigate deadly Berlin truck crash as 'presumed terrorist attack' “, in: The Guardian, 20.12.2016; URL: https:/www.theguardian.com/world/2016/dec/19/berlin-truck-crashes-intochristmas-market (as per 16.02.2018).

[10] "Terror in Berlin How the Attack Has Changed the Country", in: Spiegel Online, 23.12.2016; URL: http://www.spiegel.de/international/germany/berlin-terror-reconstruction-of-the-breit scheidplatz -attack-a-1127251.html_(as per 16.02.2018).

[11] "Deutsche Telekom upgrades wiretapping protection in mobile communications", 12.09.2013; https://www.telekom.com/en/media/media-information/archive/deutsche-telekom-upgradeswiretapping-protection-in-mobile-communications-360314 (as per 21.02.2018)

[12] “26/11 Mumbai terror attacks: Here's what happened at Taj Mahal Hotel, Trident-Oberoi, Nariman House", The Indian Express; http://indianexpress.com/article/26-11/timeline/2611mumbai-terror-attacks-heres-what-happened-at-taj-mahal-hotel-trident-oberoi-nariman-house/ (as per 21.02.2018) 
[13] Drucksache 18/10598 vom 09.12.2016 des Deutschen Bundestages, Seite 9.

[14] Welt: Bayern: Während Amoklaufs fiel der Polizeifunk minutenlang aus; URL: https://www.welt.de/regionales/bayern/article158909962/Waehrend-Amoklaufs-fiel-derPolizeifunk-minutenlang-aus.html (as per 06.08.2017)

[15] Kölner Stadt-Anzeiger: Polizeibeamter berichtet: Funknetz war in der Silvesternacht zeitweise ausgefallen; URL: http:/www.ksta.de/politik/polizeibeamter-berichtet-funknetz-war-in-dersilvesternacht-zeitweise-ausgefallen-24380364 (as per 06.08.2017)]

[16] RTL Info: Attentats à Bruxelles: voici pourquoi la police a dû communiquer via Whatsapp pendant les opérations de secours; URL: https://www.rtl.be/info/belgique/faitsdivers/attentats-a-bruxelles-voici-pourquoi-la-police-a-du-communiquer-via-whatsapppendant-les-operations-de-secours-805347.aspx (as per 21.02.2018)

[17] Rundfunk Berlin-Brandenburg: Nach Störungen beim Digitalfunk: Berlin will für seine Polizisten 16.000 Handys kaufen; URL: https:/www.rbb-online.de/politik/beitrag/2017/03/ berlin-polizei-handys-polizeifunk.html (as per 06.08.2017)

[18] Real Time Cryptanalysis of A5/1 on a PC; by Alex Biryukov, Adi Shamir and David Wagner; URL: https://cryptome.org/a51-bsw.htm_ (as per 23.02.2018)

[19] Promoting the Digitization of Japanese Fire Prevention/Emergency Wireless Communications Systems; by Kawabata Masaaki; NEC Technical Journal/Vol.8 No.1/Special Issue on Solving Social Issues Through Business Activities, p 53-58, downloadable at https://www.nec.com/en/global/techrep/journal/g13/n01/pdf/130112.pdf_ (as per 5.05.2018) 